\title{
Providing Legal Protection for Victims of Child Trafficking and Women (Case Study: North Sumatera, West Sumatera and South Sumatera)
}

\author{
Mety Rahmawati ${ }^{1}$ \\ \{Metyargo@gmail.com/ metyargo@trisakti.ac.id ${ }^{1}$ \} \\ Universitas Trisakti, Jakarta Indonesia ${ }^{1}$
}

\begin{abstract}
North Sumatera, West Sumatera dan South Sumatera is an area for transit and purpose for human trafficking. The victim is suffering physically and psychologically. This can cause trauma on victims. Victims usually withstand psychological trauma that occurs the investigation process where the victim recallas the event.The purpose of this study is to get an overview of the legal protection efforts carried out by local governments against child trafficking victims and women with case study in North Sumatera, West Sumatera and South Sumatera. Analitical Descriptive methode by using secondary data and supported by primary data. All area in this study already have regional regulation which has regulated preemtive and preventive prevention, by organizing the task force for the prevention and handling of crimes human trafficking. Providing legal protection for victims child trafficking and woman are done by mentoring, giving health service, legal assistance, repatriation and reintegration. Providing legal protection for trafficking victims varies, this is due to the different modes in each region, as well as available facilities and funds. The poverty factor, reluctant to report and awareness of the need for legal protection for trafficking victims, is an obstacle that must be overcome by the regional government gradually.
\end{abstract}

Keywords: Legal Protection, Child Trafficking. Women Trafficking

\section{Introduction}

Arist Merdeka S, as chair of the antional commission for child protection/ National commission, said thar there were networks in west Sumatera, Jakarta, Lombok, Bali, Batam and Lampung, which were neatly organized ${ }^{1}$. The human trafficking network is one of the modes of criminal trafficking in persons, which is organized crime. By way of debt bondage, the promise of a big salary and guaranteed a happy life, can get free pilgrimage, contract marriages, illegal adoption, abuse of abuse of authority, service integration, identity change and others ${ }^{2}$. Whereas for syndicates who trade people will benefit greatly: with relentless payment of debts from victims, benefits by employing children (because they are easily persuaded and paid low), transplanting organs at high prices but paid to the

\footnotetext{
${ }^{1}$ https://news.okezone.com/read/2016/09/06/337/1482519/perdagangan-anak-di-sumbar-terungkap-tigakorban-diamankan (download augts 2, 2018, at:10.20 AM).

2 https://www.bphn.go.id/data/documents/koordinasi_antar_lembaga_dalam_pemberantasan_perdaganga n_anak.pdf (download augst 2, 2018, time: 13.20 AM).
} 
victims a little or from kidnapping people whose organs are taken for sale, etc. Victims can be identified as poor people living in slums/ remote areas; child victims of domestic violence; street children; immigrant workers and other victims ${ }^{3}$. Another victim was an elderly man who has a mental illness, then exploited as a beggar.

Suffering suffered by Demisien J Silitonga who has reported the case of trafficking in persons who befell his wife, then the existence of his wife is unknown, after being given a high salary. Demisien reported the case to the North Sumatera Regional Police on 15 December 2016, but there is no clarity, this is because the employer has fled. ${ }^{4}$

Medan and Padang were place of transit and the purpose of trafficking children and woman according to internal considerations local regulation Medan No.3 of 2017 about prevention and handling woman and child as victim human trafficking.

Three teenagers from Duren Tiga, Pancoran, South Jakarta, became victims of trafficking cases (human trafficking) who were employed without the knowledge of their parent. They were hired as guest assistants at a café in Pasaman, West Sumatera As revealed by the head of Public Information at the National police headquarters, Comr.Martinus Sitompul, there were three daughters who were victims of the initials $\mathrm{P}$ (18), SZ (15), dan D (12). ${ }^{5}$

On August 15, 2018, it was reported that a woman from the southern Sumatera province of Empatlawang has been a victim of trafficking, in Lombok (NTB), a victim sold in NTB planned to be employed in Malaysia. ${ }^{6}$

Human trafficking can cause suffering, there are 2 kind of exploitation in human trafficking, according to migrant care ${ }^{7}$ : a). work exploitation occurs in women and men with the type of work in farm sector $(4,6 \%)$, construction sector $(2,1 \%)$, factory sector $(2,4 \%)$. Domestic workers both women and children come from 56,2\% of Indonesian migrant workers, the majority of female servants come from $2,4 \%$ of Indonesian migrant workers. Exploitatiom such as physical violence, psychological violence, sexual violence, unpaid wages, deprivation of food and water, ideological pressure to ban worship and the pressure to consume narcotics. b) sexual exploitation occurs in $16 \%$ of victim of Indonesian women's trafficking and as many as $35 \%$ are girls. Similarly, women who work in the sex industry experience violence and food an water deprivated. While girls who work in the sex industry are under pressure from consuming narcotics and alcohol.

The impact on victims of trafficking is the emergence of trauma to victims who are often in the form of physical and psychological damage to the victim. Victims usually withstand psychological trauma that occurs during the investigation process where the victim recalls the event. In addiction, difficulties were also felt in the criminal justice process where the victim refused to participate because of fear, stigma attached to him, revitalization, and loss of confidence in the justice system. ${ }^{8}$

\footnotetext{
${ }^{3}$ Ibid.

http://www.tribunnews.com/regional/2017/10/02/derita-demisien-yang-ditinggal-istri-jadi-korban perdagangan-orang (download:1 Augts 1,2018, at: 12.10 AM).

https://news.okezone.com/read/2016/09/02/337/1479880/tiga-gadis-cantik-jadi-korban-trafficking-disumbar (download, August 2, 2018; at: 21.00 AM).

${ }^{6} \mathrm{http} / / /$ palembang.tribunnews.com/2018/08/15/dikabarkan-seorang-wanita-asal-kabupaten-empatlawangsumsel-jadi-korban-human-trafficking-di-ntb. (download: Augst 2, 2018: at: 21.10 AM).

$7 \mathrm{http}: / / \mathrm{www} . m i g r a n t c a r e . n e t / 2017 / 01 /$ perdagangan-manusia-dan-pekerja-migran-dari-indonesia/ (download: Augst 3, 2018; at: 08.30 AM).

${ }^{8}$ Ibid.
} 
In addiction, based on the trafficking report of United Embassy in 2017, stated that many cases of trafficking in criminal acts were unclaer, due to a lack of understanding of anti rafficking laws causing some prosecutors and judges to reject cases, or to use other laws to prosecute traffickers. ${ }^{9}$ So that legal protrection is not achieved against the victims, so the victims feel that their rights are not valued.

Protection is all efforts to fulfill the rights and the provision of assistance to provide a sense of security tp witnesses aand / or the victims that's must be carried out by the LPSK (witness and victims protection agencies) or other institutions in accordance with the provision of this law. (Art. 1 paragraph (8)Law No. 31 of 2014).

Legal protection was very important for many people, cause we can be victim or can be a criminal ${ }^{10}$.

\section{Problem}

What have government done for providing legal protection and what are the obstacle in the field? (Case study: North Sumatera, West Sumatera, and South Sumatera)

\section{Research Methode}

Research uses secondary data and is supported by primary data. The regulations used are Law No. 21 of 2007 concerning the eradication of human trafficking; Law No. 31 of 2014 concerning Change of Law No, 13 of 2006 concerning witness and victim protection; Law No. 26 of 2001 concerning Human Rights Court; Government Regulation No. 9 of 2008 concerning Procedures and Integrated Service Mechanisms for witnesses nd/ or Victims of Human Trafficking; Presidential Regulation No. 69 of 2008 concernig the Task Force for the Preventon and handling of crimes in Human Trafficking; Regulation of the State Minister for Women's Empowerment and child protection Republic of Indonesia No. 22 of 2010 concerning ntegrated Service Operational standar Procedure for Witnesses and/ or victims of human trafficking; Medan area Regulation No 3 of 2017 concerning prevention and handling of human trafficking; Regulation of the Governoor West Sumatera No. 28 of 2017 concerning the descriotion of the main task and functions of the Office of Women's Empowerment and child protection and Local Regulation South Sumatera Provision No. 13 year 2017 about Prevention and handling woman and child human trafficking.

Resource persons are KPAID (Regional Indonesian Child Protection Commission) North Sumatera, the Center of integrated service for women and children empowerment (P2TP2A) Kaban Jahe North Sumatera, BP3TKI Medan, Nurani Perempuan (Padang), P2TP2A Limpahpei Rumah Nan Gadang Wet Sumatera, KPAI South Sumatera, P2TP2A women's quality of life section PP Bureau, South Sumatera Regional Secretary, south Sumatera BP3A, South Sumatera Provincial Crime Prevention and Handling Task Force.

\footnotetext{
${ }^{9}$ https://id.usembassy.gov/id/laporan-tahunan-perdagangan-orang-2017/ (download, Augst 3, 2018; at 09.00 AM).

${ }^{10}$ Dikdik M Arif M\& Elisatris Gultom. Urgency victim protection from crime between Norm and Reality. (Rajawali Pers. Jakarta.2007). P.31.
} 
Research location are North Sumatera, West Sumatera and South Sumatera. The analysis is carried out qualitatively, with the nature of analytical descriptive research.

Research locations are North Sumatra, West Sumatra, and South Sumatra.

\section{Discussion}

In article 1 law No. 21 of 2007, human trafficking is:

"The act of hiring, transporting, storing, sending, transferring, or accepting someone with the threat of violence, the use of violence, kidnapping, confinement, forgery, fraud, abuse to the power or vulnerable position, debt bondage or giving a fee or benefit, so as to obtain approval from the person hold control over the other person, whether carried out within the country or between countries, for the purpose of exploitation or resulting exploitation".

Based on the Article, that the crime of human trafficking is: the exixtence of acts in the form of recruitment, transfer or acceptance of someone, by using the threat of violence, use of violence, kidnapping, confinement, counterfeiting, fraud, abuse of power of vulnerable position, debt bondage or paying or benefits, so get the approval of the person who holds control over the other person.

Whereas exploitation according to art. 1paragraph (7) Law No. 21 of 2007 is: action with or without the consent of the victim which includes but is not limited to prostitution, forced labor services, slavery or practices similar to slavery, oppression, extortion, physical, sexual, reproductive organs, or against the law of transferring or transplanting body organs and/ or tissues or utilizing the power or ability of a person by another party to benefit both materially and immaterially.

Victim is a person who experiences psychological, mental, physical, sexual, economic and /or social suffering, which is caused by a crime of trafficking in persons. (Based on Art. 1 paragraph (3) Law No. 21 of 2007).

According to Stephen Scaffer, there are victims who are biologically and socially potentil victims. Among others, children, parents, people who are physically or mentally disabled, the poor, minorities and so on are people who are easily victims. Victims in the case cannot be blamed, but the community must be responsible ${ }^{11}$.

Society is a group of individuals who have an obligation to participate in preventing and overcoming a crime. As set out in Art. 57 paragraph (1) ang paragraph (2) and Art 60 Law No, 21 of 2007. Community participating is realized through the act of providing information and/ or reporting the existence of criminal acts of human trafficking to law enforcers or authorities, or participating in dealing with victims of acts criminal trafficking.

Neither is the country based on Art 58, the government, regional government is obliged to make policies, programs, activities, and allocate budgets to carry out prevention and addressing the issue of human trafficking, in the context of preventing and handling victims of driminal acts of people. As well as to streamline and guarantee the implementation of measures the Government forms a task force consisting of

\footnotetext{
${ }^{11}$ Stephen Scaffer. The Victim and Criminal.(New York, Random House, 1968). p.67.
} 
representatives from the government, law enforcement, community of organizations, non governmental organizations, professional organizations and researchers / academics. The Regional Government forms a task force consisting of representatives from the local government, law onforcement, community organizations, non governmental organizations, professional organizations and researchers / academics. The task force is the coordinating agency in charge:

a. coordinate prevention and handling of human trafficking;

b. carry out advocacy, socialization, training and cooperation;

c. monitoring the progress of implementation of victim protection including rehabilitation, repatriation and social integration;

d. monitor the progress of law enforcement;

e. carry out reporting and evaluation.

The centrak task force is led by a minister or minister level official appointed based on the Presidential Regulation.

a. Providing legal protection in Law No. 21 of 2007 about human trafficking and Law No, 31 of 2014 about amandement for Law no 13 of 2006 about witness and victim protection.

Protection provided to victims of human trafficking is also given to the victims families. Victims are also witnesses, therefore Law No. 31 of 2014. The protection provided in Law No. 21 of 2007 is:

1) Obtaining identity confidentiality (art.44), this right is given also to the families victims and / or witnesses to the second degree, if the family of the witness and / or the victim is pshycally or psychologically threatened by another person relating to the testimony of witnesses and / or victims.

2) In order to protect witnesses and / or victims, in each province and district / city a special service room must be established at the local police office to conduct checks at the inverstigation level for witnesses and / or victims of human trafficking. (Art. 45 pragraph (1) and (2).

3) To protect witnesses and / or victims, in each district / city integrated service centers can be established for witnesses and / or victims of human trafficking. Further provisions regarding integrated service procedures and mechanisms are regulated by government regulation. (art 46 paragraph (1) and (2).

4) In the event that witnesses and or victims and their families are exposed to threats that endanger themselves, their lives and / or property, the Republic of Indonesia National Police must provide protection, both before, during and after the proceedings. (Art 47 paragraph (1) and (2).

5). Every victim of human trafficking or their heirs has the right to get restitution. Restitution in the form of compensation for: loss of wealth or income; suffering; cost for medical and/ or psychological treatment ; and / or other losses suffered by victims as a result of trafficking. (Art. 48).

6) Victims are entitled to health rehabilitation, social rehabilitation, repatriation, and social reintegration from the government if the person is experiencing physical or psychological suffering due to the crime of human trafficiking. The rights as proposed by the victim or family of the victim, friend of the victim, police, escort volunteer, or social worker after the victim reports the case he experienced or aother party reports it to the Indonesian National Police. The application is submitted to the government 
through ministers or agencies that deal with health and social problems in the region, The minister or the agency that handles rehabilitation must provide health rehabilitation, social rehabilitation, repatriation and social reintegration no later than 7 (seven) days counted since the application is submitted. For the implementation of health rehabilitation services, social rehabilitation, repatriation and social reintegrated, the Government and Regional Government are required to form social protection homes or trauma centers. For service delivery, the community or other social service institutions can also form social protection homes or trauma centers. In the event that a victim experiences trauma or an illness which endangers him due to a crime in human grafficking so that he needs immediate assistance, the minister or agency handling health and social problems in the region must provide first aid no later than 7 (seven) days after the application is submitted. In the event that a victim is abroad requires legal protection due to a crime in human trafficking, the Government of Republic of Indonesia through its representatives abroad must protect the personal and interest of the victim, and endeavour to return the victim to Indonesia at the expense of the state. In the event that the victim is a foreign national residing in Indonesia, the government of the Republic of Indonesia seeks protestin and repatriation to their home country through coordination with their representatives in Indonesia. Provision of protection in accordance with the provisions of legislation, international Law, or International customs. The victim of a crime in human trafficking, other than as referred to in this law also has the right to obtain rights and protection in accordance with the provisions of other laws and regulations. (Art 51; 52, 53 and 54).

Based on Art. 5,6,7,7A Law no 31 of 2014, witnesses and victims are entitled:

1). Obtain protection for personal, family, and poverty security, and be free from threats relating to the testimony that will, is, or has been given;

2). participate in the process of selecting and determining forms and security support;

3). Provide information without pressure;

4). Get a translator;

5). Free from entangling questions;

6). Get information about the progress of the case;

7). Get information about court decisions;

8). Get information on case the convict is released;

9). Keep their identity secret;

10). Get a new identity;

11). Get a temporary residence;

12). Get a new residence;

13). Get reimbursement of transportation costs according to needs;

14). Get legal advice;

15). Get Temporary living expenses until the deadline for protection ends; and / or

16). Get assistance.

These rights are given to witness and / or victims of criminal acts in certain cases in accordance with the Degree of the LPSK (witness and victim protection agency). In addition to the witness and / or victim, the rights granted in certain cases can be given to the perpetrator witness, reporter, and expert, including the person who can provide information relating to a criminal act. Victims of criminal trafficking, in addition to being entitled to the 16 rights above, are also entitled to: 
1). Medical assistance;

2). Psychosocial and psychological rehabilitation assistance.

Assitance is given based on LPSK decree.

Victims of criminal acts are enitled to get a Restitution in the form of:

1). Compensation for loss of wealth or income;

2). Compensation resulting from suffering directly related to a crime; and/ or

3). Reimbursement of medical and / or psychological care cost.

Submission of applications for restitution can be done before or after a court decision that has obtained permanent legal force through LPSK. In the event that a Restitution application is filed before a court decision that has obtained permanent legal force, LPSK may submit a Restitution to the public. Prosecutor to be included in the claim. In the event that a Restitution application is filed after a court decision that has obtanined permanene legal force, LPSK may submit a Restitution to the court to obtain a determination. In the event that a victim of a crime dies, restitution is given to the victim's family who are the heirs of the victim.

Witness, victim, perpetrator witness, and/ or reporter cannot be prosecuted, booth criminal and civil for the testimony and / or report that will, is, or has been given, unless the testimony is given not in good faith. In the event that there are lawsuits against witnesses, victims, suspect and / or reporters for testimony and / or reports thal will, are, or have been given, the lawsuits must be postponed to cases that they report or give testimony have been decided by the court and obtain permanent legal force.

Inside Art. 10A Law No. 31 of 2014, perpetrator witness can be given special handling in the examination process and appreciation for the testimony given. Special handling in the form of:

1). Separation of places of detention or plances of criminal conduct between the perpetrator witness and the suspect, defendant, and / or prisoner whose criminal acts are discloser;

2). Separation of filling between the perpetrator witness's file and the file of the suspect and defendant in the process of investigation, and prosecution of the criminal act disclosed; and/ or

3). Giving testimony before the court without dealing directly with the defendantwhose criminal actions were revealed.

b. Government regulation No. 9 of 2008 about Procedure and mechanism Integrated service for witness and/ or human trafficking victim.

Integrated services are a series of activities to protect witnesses and/ or trafficking victims carried out jointly by relevant agencies and institutions as one unit of health rehabilitation providers, social rehabilitation, repatriation of social integration and legal assistance for witnesses and trafficking victims. Integrated services must provide services and handling as soon as possible of witnesses and / or victims; provide convenience, comfort, safety and free of cost for witnesses and or victims; maintain the confidentiality of witnesses and or victims and ensure justice and legal certainty for witnesses and / or victims.

Integrated services are carried out by local governments. Including social rehabilitation, health rehabilitation, repatriation, advocacy, counselling and legal assistance. If the child is a victim, then the service is given specifically in the best interest of the child. 
Social rehabilitation is carried out to recover witnesses and victims from disturbances in psychosocial

Conditions and return to normal social functioning both in the family and in society. Social reintegration by reuninting witnesses and / or victims with family members, substitute families or communities who can provide protection and fulfilment of the needs of witnesses and/ or victims.

Standards service minimum and operational standars for return and social reintegrated procedures must be used as guidelines for the implementation of integrated services. Including provision of facilities and infrastructure. Witnesses and victims are entitled to health rehabilitation, social rehabilitation, repatriation, social reintegrated and legal assistance.

Integrated service leaders within 24 hours of receiving witnesses and / or victims who are being treated or recovery for their health, must report it to the nearest police officer.

Local governments that already have a social protection house or trauma center can be used to support the integrated service. If there are private institutions and the public is willing to provide these services, it can be carried out by following the mechanism and procedures for service delivery.

Victims are Indonesian citizens who outside Indonesia, through representatives of Republic of Indonesia who are in that place. Representative of the Republic of Indonesia must provide personal protection and the interest of witnesses and / or victims and return them to Indonesoa at the expense of the state. The local government is obliged to pick up and repatriate to the area of origin and other actions needed to protect witnesses and / or human trafficking.

Coordination with the regional head is carried out to take action to protect and return witnesses and / or victims. The Regent/ mayor from the origin is obliged to immediately deal with matters related to the protection interest.

In the case of witnesses and / or victims of foreign nationals, the foreign minister of the Republic of Indonesia must coordinate with representatives of relevant countries. To help repatriate. For the handling of victims, an integerated service center is obliged to network with government or private hospitals for the care and recovery of victims's health.

All PPT activities are evaluated and monitored by the ministry of empowerment of women and children.

\section{c. President Regulation No. 69 year 2008 concerning about Task force Prevention and Handling of crimes in Human trafficking.}

Task force for the prevention and handling of criminal Acts for centrak Trade Persons, hereafter referred to as the Centrak Task Force, is the coordinating agency tasked with coordinating efforts to prevent and deal with human trafficking at the national level.

The centrak task force has the following tasks: a) coordinate prevention efforts and address the problem of criminal trafficking in persons; b) carry out advocacy, socialization, training and cooperation both national and international; c). montor the progress of the implementation of victim protection which includes rehabilitation, repatriation and social reintegration; d. monitor the progress of law enforcement; and e. carry out reporting and evaluation.

In the province the provincial task force is formed in accordance with the provisions of the legislation. The provincial task force is under and responsible to the Governor. In District / cities a district / city task force is established in accordance with the provisions 
of the legislation. The district / city task force is under and is responsible to Regent / mayor.

To ensure the synergy and continuity of measures to eradicate criminal trafficking in an integrates manner, the central Task Force, the provincial Task force and the District / city Task Force coordinated and direct relations with relevant agencies and other related parties to formulate policies, programs, and activities in the from of National Action Plans and District action plans.

Monitoring the progress of the implementation of duties by the centrak task force is carried out periodically and from time to time, both through National coordination, plenary coordination, coordination of sub task forces, and special coordination, as well as direct monitoring to the field or using available communication facilities (Art. 25).

d. Regulation of the State Minister for Women's Empowerment and child protection Republic of Indonesia No. 22 of 2010 concerning integrated Service Operational standar Procedure for Witnesses and/ or victims of human trafficking.

Integrated service operational standar procedure for witnesses and / or victims of human trafficking including: a) complaint / identification service; b) health rehabilitation; c) social rehabilitation; d) legal assistance; e) return; Regulation of the State Minister for Women's Empowerment and child protection Republic of Indonesia No. 22 of 2010 concerning ntegrated Service Operational standar Procedure for Witnesses and/ or victims of human traffickingand f) social reintegration. Integrated service operational standar procedures for witnesses and/ or victims of human trafficking can be used as guidelines for Government, Indonesia citizen service units in Indonesian Representatives abroad community based integrated service centers/ community that organized integrated services for witnesses and / or victims of human trafficking. Integrated service operational standard procedure for witnesses and / or victims of criminal human trafficking carried outsystematically, coordinated, integrated and sustainable in order to fulfil the rights of witnesses and / or victims of human trafficking. In the event thar witnesses and / or victims of human trafficking are children, the operational standard procedure is carried out by taking into account the fulfilment of children's rights and the best interest of child. In implementing the standard operating procedure, the integrated service center can cooperate with the community and other relevant institutions in accordance with the provisions of the legislation. Provision / district / city trade crime prevention and handling task force monitors and evaluated the implementation of integrated service operational standard procedure for witnesses and / or victims of human trafficking at integrated service centers in their regions. Monitoring and evaluation includes system development, human recources, and networks which include: a) planning standar operational procedures; b) implementation of services and development; and c) monitoring and evaluation. The results of monitoring and evaluation are reported to the Governor, Regent and Mayor. (Based on art. 1,3,4,5,7,8,9).

\section{e. Providing legal protection in North Sumatera.}

Local government in North Sumatera, has been seek regulation to protect trafficking victims of children and women by enacting Medan Regional Regulation No 3 of 2017 concerning the prevention and handling of child and female trafficking victims.

The North Sumatera regional government has sought regulations to protect human trafficking of children and women by enacting the Medang Regional Regulation No3 of 2017 concerning the prevention and handling of child and female trafficking victims. 
Aimed at preventing and handling trafficking victims with preemptif prevention and preventive prevention. The Medan Regional Government is just trying to socialized the regulation in Medan city.

The North Sumatera region is the Simalungun (consisting of Pematang Bandar district, Huta Batu Raja and Ujung Padang; Regional District II Dairi (consisting of Parbuluan sub -district); Area II Medan (consisting of: Medan Petisah sub district, Medan Tembung, Medan Helvitia; Medan Polonia, Medan Maimun, Medan Selayang, Medan Amplas and Medan Area). All regency areas are in the North Sumatera Province area.

The North Sumatra Region is the territory of Karo District II (consisting of Brastagi and Marinding Sub-districts), Regional District II Simalungun (consisting of Pematang Bandar District, Huta Bayu Raja and Ujung Padang); Regional District II Dairi (consisting of Parbuluan sub-districts); Area II Medan (consisting of: Medan Petisah sub-district, Medan Tembung, Medan Helvetia; Medan Polonia, Medan Maimun, Medan Selayang, Medan Amplas and Medan Area. All Regency Areas are in the North Sumatra Province Area

Trafficking victims in North Sumatera, who are victims are those (children) employed on jermal; women employed as domestic servants with low salary; women employed in entertainment centers related to sexual exploitation; sale of organs by kidnapping, trafficking in babies, becoming wi=orkers abroad but not in accordance with agreement that have been signed and cases that are not recorded. The victims complains to the authorities.

P2TP2A Medan, giving data on the families of the victims coming to bring victims to be given assistance and legal assistance. Then victims who are traumatized are taken to the nearest hospital and get medical and psycho medical assistance. If the trafficking case is continued by the court, the victim will be accompanied during the examination in the court proceedings. If trafficking victims are workers who are abroad, then the repatriation is carried out by Republic of Indonesia Embassy, then reintegration. Social reintegration s done at the RPC (Home trauma center protection) owned by the Indonesian ministry.

KPAID, handles cases of child trafficking, and accompanies children and delivers to the RUPA (child protection house) owned by North Sumatera KPAID, or at other child protection homes with assistance from North Sumatera KPAID together with social workers or social ministry vounteers Repubic of Indonesia related.

The existence of child friendly madrasas and child friendly schools, played a significant role in reducing the number of child complaint cases. In 2017, there were 3849 cases affecting children and 293 cases of child victims of trafficking and child exploitation. More children as perpetrators of crime.

The repatriation has been carried out by BP3TKI (National agency for placement and protection of Indonesia workers) in Medan several times, repatriating Indonesian workers from Malaysia. This is in collaboration with the Malaysian Non Gevernmental Organization and Medan P2TP2A.

The granting of restitution and compensation as regulated in Law No. 21 of 2007 and Law No. 26 of 2001, has not yet been given

Providing protection for victims of trafficking of children and women cannot be done completely. It can not be done completey, this happens sometimes when victims are reluctant to report criminal acts of trafficking. People are less concerned, this is due to the state of the economy they are facing. Although legal awareness is a preventive prevention effort that has been announced by the Medan regional government. 


\section{f. Providing legal protection in west Sumatera.}

Government Regulation West Sumatera No. 28 year 2017 about description of the main task and function of tge office of womens empowerment and child protection of west Sumatera Provision regulate efforts to prevent and deal with child trafficking victims and women with preemtive and preventive prevention.

West Sumatera region consist of 19 district, among others: Agam; Dharmasraya; Kepulauan Mentawai; Limah Puluh Kota; Padang Pariaman; Pasaman; Pasaman Barat; Pesisir Selatan; Sijunjung; Solok (Arusuka); Solok Selatan; Tanah datar; Bukit Tinggi; Padang; Padang Panjang; Pariaman; Payahkumbu; Sawahlunto; Solok.

Trafficking victims are children and women. The form of trafficking of children with a mode of persuasion, and children are handed over to school, but are found by the police as elementary school children and cannot Bahasa; women and children brought to west Sumatera are used as entertaintmen servants, who are then known to be non indigenous people of west Sumatera, but from outside Sumatera; and child prostitution.

Data on women as trafficking victims according to crisis Nurani is from 2013 to 2016 there were 14 cases. Victims the most domestic violence in West Sumatera.

P2TP2A, help provide protection to trafficking victims, by assisting assistance and bringing to the hospital, if the victim is physically and / psychologically/ traumatized. Recovery is done pribately and returned to each family.

Providing legal protection to victims of trafficking in children and women is carried out practically. The local regulation on West Sumatera has been set up for preemptive and preventive prevention, but there has been no reduction in the number of trafficking victims.

\section{g. Providing legal protection in South Sumatera.}

Local Regulation South Sumatera Provision No. 13 year 2017 about Prevention and handling woman and child human trafficking. Local government do prevention by using a pre-emptive and preventive policy. South Sumatera region consist of 17 districts, among others: Banyuasin, Empat Lawang, Lahat, Muara Enim, Musi Banyuasin, Musi Rawas, Musi Rawas Utara, Ogan Ilir, Ogan Komering Ilir, Ogan Komering Ulu, Ogan Komering Ulu Selatan, Ogan Komering Ulu Timur, Penukal Abab Lematang Ilir, Lubuktinggau, Pagar Alam, Palembang, Prabumulih.

Victims of child trafficking and woman are victims of trafficking crimes with the following modes: become a servant in the entertaintment world; become a female workforce but treated improperly, used as prostitution; made the bride of the order; children sold; the girl sold by her boyfriend; children are made into prostitution / sexual exploitation. However, there is one case recorded in the Task Force for the prevention and handling of criminal trafficking in persons in 2017.

P2TP2A South Sumatera, do services for human trafficking victim, not as many as victims of domestic violence and rape. $\mathrm{P} 2 \mathrm{TP} 2 \mathrm{~A}$ has facilitated victims access to information, also how to do reports and complaints, as well as information toget education and job training. Safe home services are not available in South Sumatera, but served medically, if the victim suffers from physical or trauma/ non psychic. Psycological service are provided to trauma victim. BP3A South Sumatera have done it.

The public is reluctant to report about trafficking, likewise children and woman. Trafficking occurs because of poverty. 


\section{Conclusion}

Diffrence modus in human trafficking, can cause difference providing legal protection for the victim, Providing legal protection for child and woman in Nort Sumatera, West Sumatera and South Sumatera, done by each regulation. Preemtif prevention and preventif prevention are set up in each regulation in South Sumatera, West Sumatera and South Sumatera. But there is obstacles in many aspect. Such as infrastructure and services not already done. Protection are information service, accompaniment, legal asistance, return and reintegration already done. Providing legal protection base on each area condition. But, cultural factor that is still inherent, such as kesadaran akan perlunya protection for human trafficking victim, reluctant to report and poverty factor.

\section{Reference}

[1]. Dikdik M Arif M\& Elisatris Gultom. Urgency victim protection from crime between Norm and Reality. (Jakarta, Rajawali Pers, 2007).

[2]. Muladi. Human rights: The nature, concept and implications in a legal and community perspective. (Bandung, Refika Aditama, 2005).

[3]. Scaffer, Stepehn. The Victim and Criminal.(New York, Random House, 1968).

[4]. Law No. 21 of 2007 concerning the eradication of human trafficking;

[5]. Law No. 31 of 2014 concerning Change of Law No, 13 of 2006 concerning witness and victim protection;

[6]. Law No. 26 of 2001 concerning Human Rights Court;

[7]. Government Regulation No. 9 of 2008 concerning Procedures and Integrated Service Mechanisms for witnesses nd/ or Victims of Human Trafficking;

[8]. Presidential Regulation No. 69 of 2008 concernig the Task Force for the Preventon and handling of crimes in Human Trafficking;

[9]. Regulation of the State Minister for Women's Empowerment and child protection Republic of Indonesia No. 22 of 2010 concerning ntegrated Service Operational standar Procedure for Witnesses and/ or victims of human trafficking;

[10]. Medan area Regulation No 3 of 2017 concerning prevention and handling of human trafficking; Regulation of the Governoor West Sumatera No. 28 of 2017 concerning the descriotion of the main task and functions of the Office of Women's Empowerment and child protection.

[11]. Local Regulation South Sumatera Provision No. 13 year 2017 about Prevention and handling woman and child human trafficking; 